\title{
Dickinsonia costata - the first evidence of neoteny in Ediacaran organisms
}

\author{
M.A. Zakrevskaya, A.Yu. Ivantsov \\ A.A. Borissiak Paleontological Institute of RAS, Profsoyuznaya st., 123, Moscow, 117647, Russia. \\ E-mail: mariazakrevskaya@gmail.comivancov@paleo.ru
}

ABSTRACT: Some of the most famous organisms of the Late Precambrian are representatives of the genus Dickinsonia. Four species of Dickinsonia are found throughout the section, characterized by macrofossils, on the southeastern White Sea area. However, their distribution is uneven. Two species, $D$. costata and $D$. tenuis are the most common, while the other two occur sporadically. At the lower levels (Verkhovka Formation) thinsegmented $D$. tenuis is the most frequently encountered. There are few imprints that can be attributed to $D$. costata, and all of them are of small size. Numerous specimens of $D$. costata, representing all available for study stages of ontogeny, are present only at the upper stratigraphic levels - in the Zimnie Gory and Erga formations. The statistical analysis of Dickinsonia imprints from a number of fossil assemblages in the southeastern White Sea shows an existence of two distinct groups that could represent different stages of ontogeny of a single species - D. tenuis. All the features of the juvenile $D$. tenuis - a round body, enlarged head part and a small number of trunk isomers - are distinctive features of $D$. costata. These features are preserved in mature D. costata. The most likely explanation of this phenomenon is the origin of $D$. costata from $D$. tenuis by neoteny.

How to cite this article: Zakrevskaya M.A., Ivantsov A.Yu. 2017. Dickinsonia costatathe first evidence of neoteny in Ediacaran organisms // Invert. Zool. Vol.14. No.1. P.92-98. doi: 10.15298/invertzool.14.1.13

KEY WORDS: Ediacaran biota, Vendian, Metazoa, Invertebrate paleontology, Dickinsonia.

\section{Dickinsonia costata - первое свидетельство неотении у эдиакарских организмов}

\author{
М.А. Закревская, А.Ю. Иванцов
}

Палеонтологический институт им. А.А. Борисяка РАН, Профсоюзная ул., 123, Москва, 117647, Росcuя.E-mail: mariazakrevskaya@gmail.comivancov@paleo.ru

РЕЗЮМЕ: Одними из самых известных организмов позднего докембрия являются представители рода Dickinsonia. На территории Юго-Восточного Беломорья 4 вида дикинсоний встречаются по всему разрезу, охарактеризованному макроископаемыми. Однако распределение их неравномерно. Наибольшее распространение имеют два вида D. costata и D. tenuis, а два других встречаются спорадически. На нижних уровнях (верховская свита) наиболее часто встречается тонкосегментная D. tenuis, a отпечатков, которые можно было бы отнести к D. costata мало и все они мелкого размера. Многочисленные остатки D. costata, отражающие все доступные для на- 
блюдения стадии онтогенеза этого вида, присутствуют только на верхних уровнях в зимнегорской и ергинской свитах. Проведенный статистический анализ совокупности отпечатков дикинсоний из ряда захоронений Юго-Восточного Беломорья показал существование 2 четких групп, которые могут представлять собой различные стадии онтогенеза одного вида - D. tenuis. Все признаки ювенильных D. tenuis округлое тело, широкий головной отдел и небольшое количество туловищных изомеров - являются характерными признаками D. costata и сохраняются у нее во взрослом состоянии. Наиболее вероятным объяснением выявленного феномена является происхождение D. costata от D. tenuis путем неотении.

Как цитировать эту статью: Zakrevskaya M.A., Ivantsov A.Yu. 2017. Dickinsonia costata - the first evidence of neoteny in Ediacaran organisms // Invert. Zool. Vol.14. No.1. P.92-98. doi: 10.15298/invertzool.14.1.13

КЛЮЧЕВЫЕ СЛОВА: эдиакарская биота, вендский период, Metazoa, палеонтология беспозвоночных, Dickinsonia.

\section{Introduction}

Dickinsonia Sprigg, 1947 is one of the most typical and world-known fossil taxa of the Ediacaran (Vendian) age. It was described originally from the upper Ediacaran (Pound Quartzite) of the Flinders Ranges in South Australia. The genus is common in marine strata of eastern Europe and South Australia. The flat bilaterally symmetrical body of Dickinsonia consists of two parts - head and trunk ones. The trunk part is divided into numerous transverse elements isomers, located on both sides of the body in an alternating pattern. The head part of mature individuals is almost indistinguishable from isomers by its overall size and size ratios.

Dickinsonia costata Sprigg, 1947 is the type species of the genus. It is characterized by a round shape with the length/width ratio approaching $1: 1$, by a small number of isomers with relatively large width, and by the enlarged head part.

During 70 years of the study of Dickinsonia, understanding of this genus was changed radically. At the beginning, Dickinsonia was interpreted as coelenterates of uncertain origin (Sprigg, 1949) and as annelids (Glaessner, Wade, 1966). D. Seilacher combined Dickinsonia along with the rest of the Vendian biota into the special extinct kingdom of Vendobionta on the basis of their specific features, such as the chambered construction, the symmetry of the sliding reflec- tion, a presumable absence of the oral opening and distinct inner structures (Seilacher, 1989, 1992). He suggested that Dickinsonia was feeding by absorbing dissolved organic matter by the entire body surface using chemo- or photosymbionts. Later on, Seilacher reduced the composition of the Vendobionta and lowered the rank of this group to a class level within rhizopod protozoans (Seilacher et al., 2003). G. Retallack suggested that Dickinsonia was remains of fungi or lichens on the basis of its leaf shape and unlimited growth (Retallack, 1994). E. Sperling and J. Vinther proposed a hypothesis on the placozoan level of organization of alike Vendian organisms, based on the assumption that Dickinsonia fed by external digestion (Sperling, Vinther, 2010). Dickinsonia was also interpreted as ancestral chordates (Dzik, 2003). According to the most compelling suggestions, Dickinsonia is classified as the Proarticulata, an extinct phylum of benthic mobile multicellular animals (Fedonkin, 1990). This statement was confirmed by the finds of Dickinsonia trace fossils in association with the body imprints of the trace maker(Ivantsov, Malakhovskaya, 2002; Gehling et al., 2005; Evans et al., 2015). The pattern of Dickinsonia trace fossils revealed that this animal fed on upper surface of microbial mats using its ventral side (Ivantsov, 2011, 2013). Distinct internal structures, interpreted as digestive-distributive systems, were also found in some specimens of Dickinsonia (Ivan- 
tsov, 2004). An indirect evidence of this organism mobility can also be derived from the study of paleocommunities. In paleocommunities consisting of juveniles only and almost lacking mature individuals, very large single individuals of Dickinsonia costata occur. Such individuals, representing the previous generation, probably migrated from nearby areas and gave the birth to juveniles that formed a new paleocommunity (Zakrevskaya, 2014).

Dickinsonia is the richest genus of the late Precambrian macroorganisms. At present, nine species of this genus were described: $D$. costata, D. tenuis, D. lissa, D. menneri, D. rex, D. brachina, D. minima, D. spriggi, and D. elongata. However, the majority of these species probably are synonyms. In the White Sea sections, four species only are found, namely $D$. costata, D. tenuis, D. lissa, D. menneri. They differ primarily by ratios of body dimensions and by the width of transverse elements (isomers) and the head part. Of them, D. costata and D. tenuis only are present in a significant number to use statistical analysis.

\section{Materials and methods}

Dickinsonia specimens are collected in the southeastern White Sea area (Arkhangelsk region) by the Precambrian team of the A.A. Borissiak Paleontological Institute of RAS and housed in the Laboratory of Precambrian Organisms of this institute.

The fossils were preserved in situ as imprints on sandstone bottom surfaces (Flinderstype preservation; Narbonne, 2005), as a result of burial of benthic paleocommunities by storm sediments. In the White Sea section, a series of successive burials is observed at different stratigraphic levels embracing an interval of over 3 million years (Martin et al., 2000; Llanos et al., 2005). Dickinsonia is found throughout the section, characterized by macrofossils. However, generally only thin-segmented $D$. tenuis occurs at the lower levels (the Verkhovka Formation) while imprints that can be attributed to $D$. costata are few and small. Numerous specimens of
D. costata preserving all the stages of ontogeny available for study are restricted to the upper levels, in the Zimnie Gory and Erga formations.

For the statistical analysis of the fossil imprints, over 500 specimens, presumably belonging to different species of Dickinsonia, were measured. The length and the width of each imprint (with $0.1 \mathrm{~mm}$ precision), the number of its isomers, and the width of the first isomer at its widest dimension are measured in 220 specimens of Dickinsonia. Fragmentary preservation of other specimens does not allow us to include them in our analysis. However, an excellent preservation of the majority of the White Sea specimens bearing the finest details provides an opportunity to make necessary measurements even in the smallest individuals.

\section{Results and discussion}

A statistical analysis has been applied to the imprints of both D. tenuis and D. costata from a number of burials in the Verkhovka and Erga formations, respectively, of the Karakhta and Zimnie Gory localities (Zakrevskaya, Ivantsov, 2015). Due to certain peculiarities of the formation of Flinders-type localities, each fossil assemblages of a burial reflects directly the preburial state of populations and is not enriched or depleted during posthumous processes. The resulting plots show a variation in the number of isomers and the width of the first isomer of Dickinsonia in relation to the body size (length, width). The body length of $D$. tenuis being figured against the width of its first isomer reveals a bimodal distribution of these dimensions (Fig. 1). The first group is represented by small-sized specimens with a wide head part, and the second group — by larger specimens with a narrow head part. These two sets of individuals are distinct and their ratio variables do not overlap.

The ratio of the length to the number of isomers also demonstrates a similar division into two groups for D. tenuis (Fig. 2), where the first group is characterized by a small number of isomers and a small body size, and the second one - by a large number of isomers and a bigger 


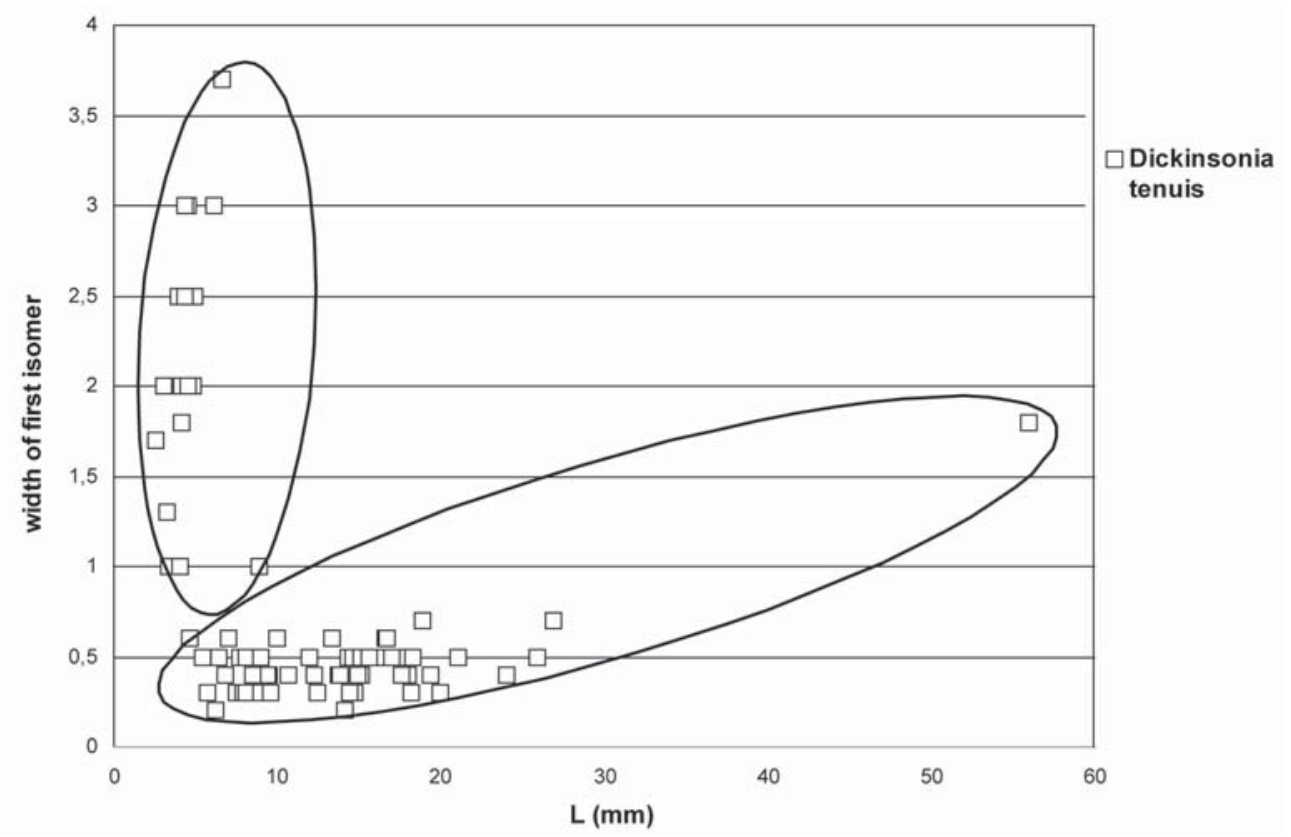

Fig. 1. Ratio of length to width of the head part of Dickinsonia tenuis from Karakhta locality. Рис. 1. Соотношение длины и ширины головного отдела Dickinsonia tenuis из Карахтинского местонахождения.

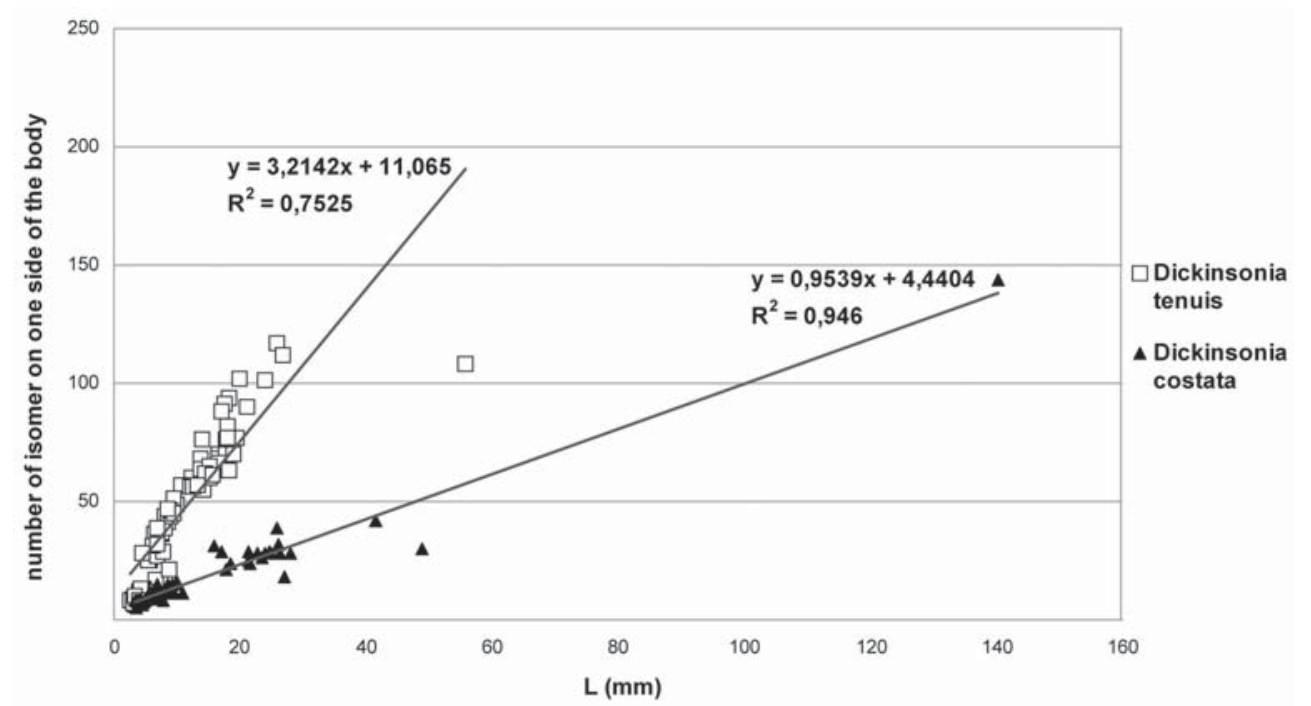

Fig. 2. Ratio of length to number of isomers in Dickinsonia tenuis from Karakhta locality and D. costata from Zimnie Gory locality.

Рис. 2. Соотношение длины и количества изомеров у Dickinsonia tenuis из Карахтинского и Dickinsonia costata из Зимнегорского местонахождения. 


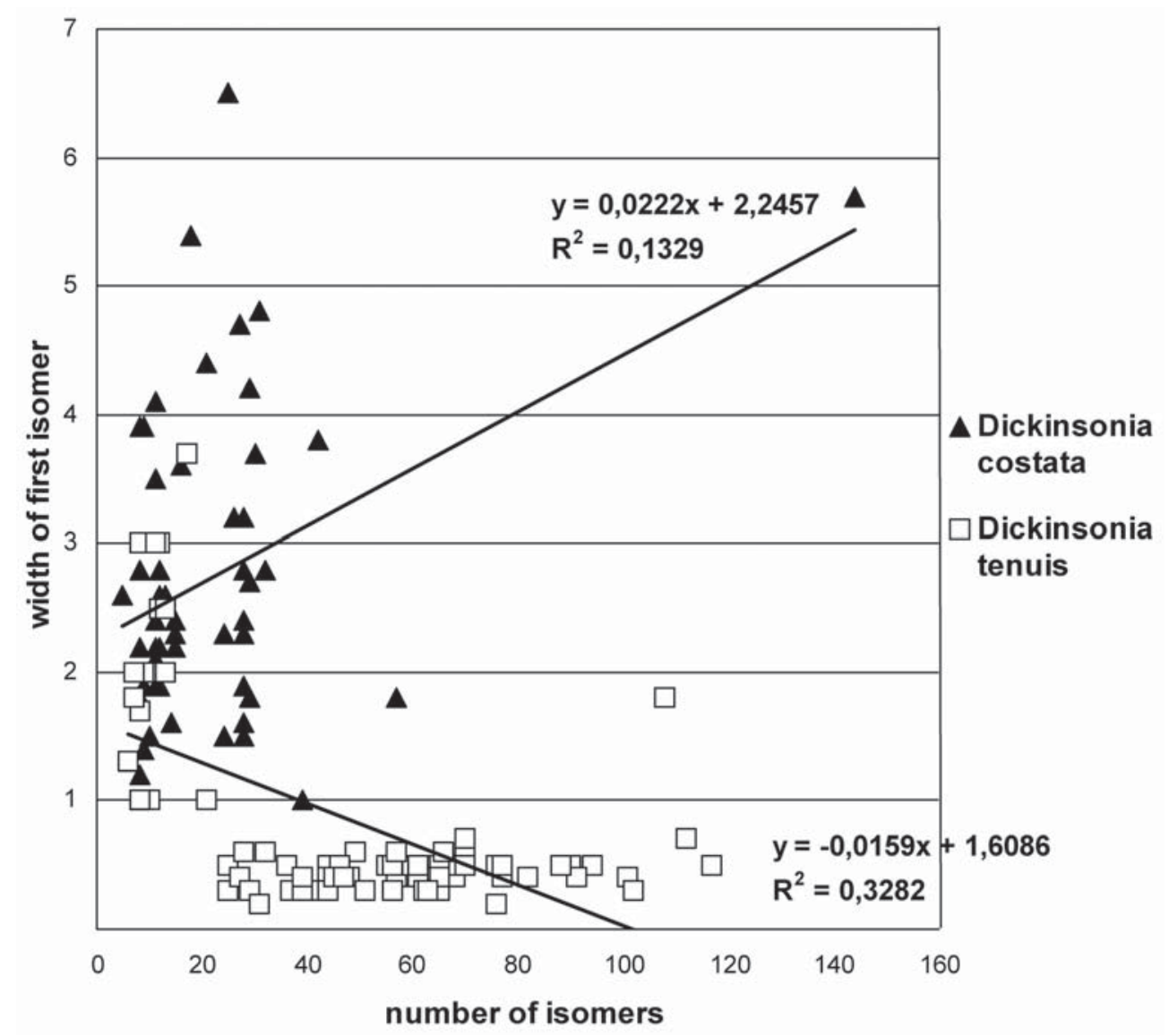

Fig. 3. Ratio of number of isomers to width of the head part in the widest section of Dickinsonia tenuis from Karakhta and D. costata from Zimnie Gory locality.

Рис. 3. Соотношение количества изомеров и ширины головного отдела в самой широкой его части у Dickinsonia tenuis из Карахтинского и Dickinsonia costata из Зимнегорского местонахождения.

size. The plot shows that the size ratios of the first group correlate with same ratios of $D$. costata from the Zimnie Gory locality (marked by black triangles) and together these data compile a single linear trend. Such a pattern keeps pass in $D$. costata throughout the entire length range up to very large specimens (up to $140 \mathrm{~mm}$ in length). In D. tenuis, as the size increases, the linear trend abruptly changes its direction, and the growth in the number of isomers overcomes the increase in size of larger individuals compared to smaller ones.

The same pattern is observed on the plot showing the ratio of the number of isomers to the width of the first isomer for the same specimens of D. tenuis and D. costata (Fig. 3). An overlap of dimensions of the smallest $D$. tenuis with those of $D$. costata is observed, where the latter is distinguished by the presence of a wide head part and a small total number of isomers. Over specimens of $D$. tenuis form a separate set that does not overlap with the previous one and is characterized by a gradually increasing total number of isomers and a constant very small relative width of the head part, which is much inferior to the width of the head part in specimens from the first set.

In fossil assemblages of the Karakhta locality, all small individuals of Dickinsonia are characterized by body dimensions of $D$. costa- 


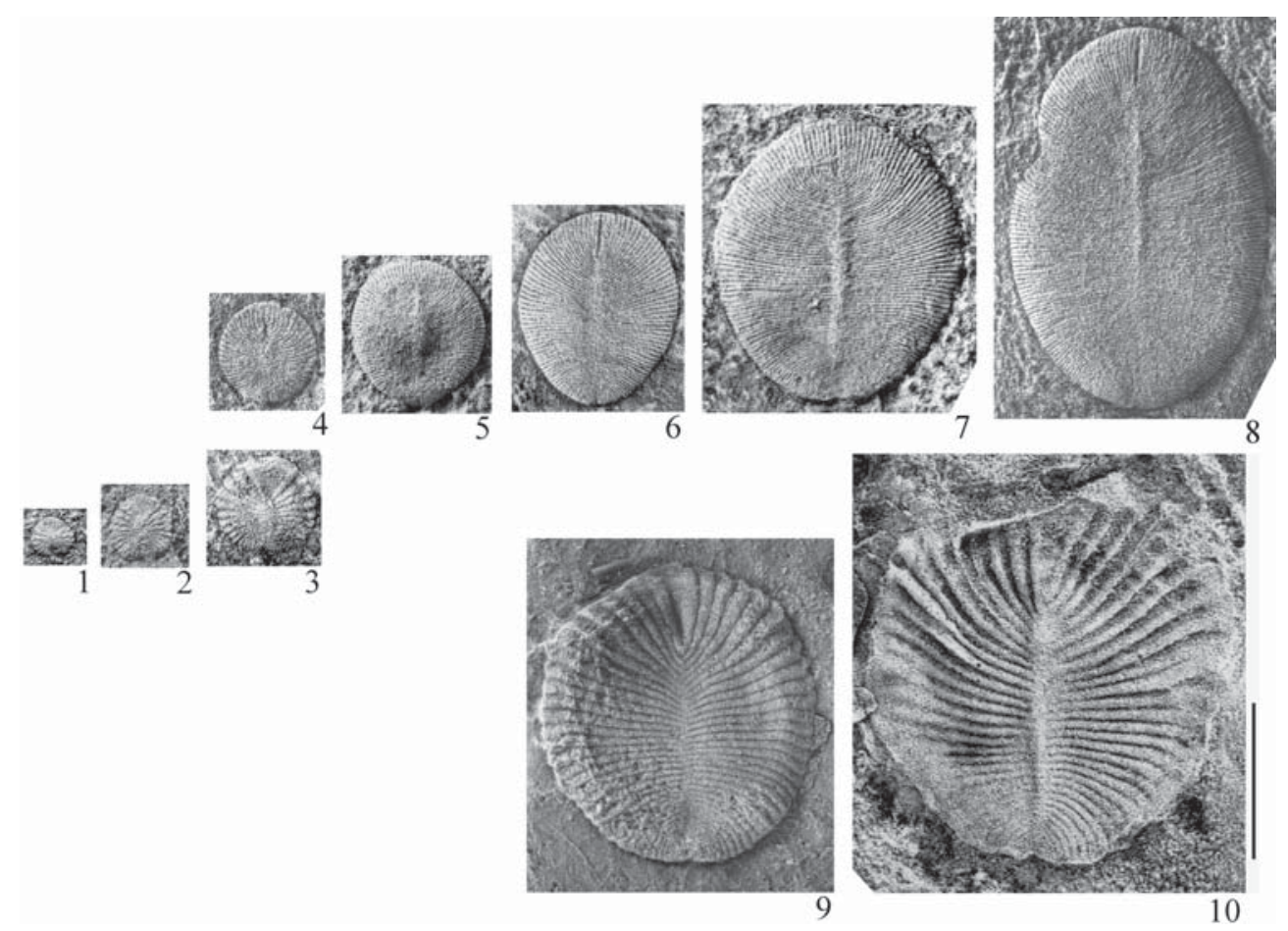

Fig. 4. Individual development of Dickinsonia. 1-8 - a part of the ontogeny series of D. tenuis based on specimens from Karakhta locality (1-3 - juveniles); 9, $10-D$. costata from Zimnie Gory locality; latex casts of the specimens from the PIN RAS collection, nos.: 1 - specimen PIN, No 4852/38, 2 - 4852/39, $3-4852 / 33,4-4852 / 79,5-4852 / 60,6-4852 / 30,7-4852 / 44,8-4852 / 17,9-3993 / 5107,10$ - 3993/5243. Scale bar $1 \mathrm{~cm}$.

Рис. 4. Возрастные преобразования тела дикинсоний. 1-8 - фрагмент онтогенетического ряда Dickinsonia tenuis по материалам Карахтинского местонахождения (1-3 - ювенильная стадия); 9, 10 - Dickinsonia costata из Зимнегорского местонахождения; латексные слепки с экземпляров коллекции ПИН РАН, №№: 1 - 4852/38, 2 - 4852/39, 3 - 4852/33, 4 - 4852/79, 5 Ï 4852/60, 6 4852/30, 7 - 4852/44, 8 - 4852/17, 9 - 3993/5107, 10 - 3993/5243. Длина масштабного отрезка $1 \mathrm{~cm}$.

$t a$, and all larger individuals have features typical of D. tenuis (Fig. 4). The transition from the first set to the second one is abrupt but no gap in the sequence is observed. In this regard, we suggest that both sets represent different stages of ontogeny of the same species - D. tenuis. The transition is accompanied by a discontinuous growth and by a sharp, almost double increase in the number of trunk isomers, as well as a reduction in the width of the head part. Thus, the body assumes the appearance of a typical $D$. tenuis. The well-marked morphological differences between early and later stages of develop- ment can be indicative of the fact that Dickinsonia had a distinct juvenile stage and this stage was characterized by an ecology different from that of mature individuals.

It can be seen that all the features of juvenile D. tenuis — the round body, the wide first isomer and a small number of isomers - are characteristics of $D$. costata and remain so at mature stages (Fig. 3, 4). These observations can indicate a probable origin of $D$. costata from $D$. tenuis by the neoteny. This is the first case of neoteny being observed in Precambrian organisms. 
The work was supported by the RFBR grant No. 17-05-02212-a.

\section{References}

Dzik J. 2003. Anatomical information content in the Ediacaran fossils and their possible zoological affinities // Integrative and Comparative Biology. Vol.43. P.114-126.

Evans S.D., Droser M.L., Gehling J.G. 2015. Dickinsonia liftoff: Evidence of current derived morphologies // Palaeogeography, Palaeoclimatology, Palaeoecology. Vol.434. P.28-33.

Fedonkin M.A. 1990. Systematic description of the Vendian Metazoa // B. Sokolov, A. Ivanovski (eds.). The Vendian System 1, Paleontology. New York: Springer-Verlag. P.71-120.

Gehling J.G., Droser M.L., Jensen S., Runnegar B.N. 2005. Ediacaran organisms: relating form to function // D.E.G. Briggs (ed.). Evolving Form and Function: Fossils and Development. Proceedings of a Symposium Honoring Adolf Seilacher for His Contributions to Palaeontology in Celebration of His 80th Birthday. New Haven: Yale University. P.43-67.

Glaessner M.F., Wade M. 1966. The Late Precambrian fossils from Ediacara, South Australia // Palaeontology. Vol.9. P.599-628.

Ivantsov A.Yu. 2004. New Proarticulata from the Vendian of Arkhangelsk Region // Paleontological Journal. Vol.38. No.3. P.247-253.

Ivantsov A.Yu. 2011. Feeding Traces of Proarticulata the Vendian Metazoa // Paleontological Journal. Vol.45. No.3. P.237-248.

Ivantsov A.Yu. 2013. Trace Fossils of Precambrian Metazoans "Vendobionta" and "Mollusks" // Stratigraphy and Geological Correlation. Vol.21. No.3. P.252264.

Llanos M.P.I., Tait J.A., Popov V., Abalmassova A. 2005. Palaeomagnetic data from Ediacaran (Vendian) sediments of the Arkhangelsk region, NW Russia: an alternative apparent polar wander path of Baltica for the Late Proterozoic - Early Palaeozoic // Earth and Planetary Science Letters. Vol.240. P.732-747.
Martin M.W., Grazhdankin D.V., Bowring S.A., Evans D.A.D., Fedonkin M.A., Kirschvink J.L. 2000. Age of Neoproterozoic Bilatarian Body and Trace Fossils, White Sea, Russia: Implications for Metazoan Evolution // Science. Vol.288. No.5467. P.841-845.

Narbonne G.M. 2005. The Ediacara biota: Neoproterozoic origin of animals and their ecosystems // Annual Review Earth Planet. Science. Vol.33. P.421-442.

Retallack G.J. 1994. Were the Ediacaran fossils lichens? // Paleobiology. Vol.20. P.523-544.

Seilacher A. 1989. Vendozoa: Organismic construction in the Proterozoic biosphere // Lethaia. Vol.22. No.3. P.229-239.

Seilacher A. 1992. Vendobionta and Psammocorallia: lost constructions of Precambrian evolution // Journal of the Geological Society. London. Vol.149. No.4.P.607613.

Seilacher A., Grazhdankin D., Legouta A. 2003. Ediacaran biota: The dawn of animal life in the shadow of giant protests // Paleontological research. Vol.7. No.1. P.43-54.

Sperling E.A., Vinther J. 2010. A placozoan affinity for Dickinsonia and the evolution of late Proterozoic metazoan feeding modes // Evolution \& Development. Vol.12. P.201-209.

Sprigg R.C. 1947. Early Cambrian (?) Jellyfishes from the Flinders Ranges, South Australia // Transactions of The Royal Society of South Australia. Vol.71. No.2. P.212-224.

Sprigg R.C. 1949. Early Cambrian "Jellyfishes" of Ediacara, South Australia and Mouth John, Kimberley District, Western Australia // Transactions of The Royal Society of South Australia. Vol.73. No.1. P.72-99.

Zakrevskaya M.A. 2014. Paleoecological reconstruction of the Ediacaran benthic macroscopic communities of the White Sea (Russia) // Palaeogeography, Palaeoclimatology, Palaeoecology. Vol.410. P.27-38.

Zakrevskaya M.A., Ivantsov A.Yu. 2015. [Evolution of views on the nature of Dickinsonia costata (metazoan of the Vendian period)] // Sovremennye problemy paleontologii. Materialy LXI sessii Paleontologicheskogo obshchestva pri RAN. Sankt-Peterburg. P.40-42 [in Russian].

Responsible editor E.N. Temereva 